\title{
COMPARISON OF MODULE EFFECTIVENESS TO IMPROVE KNOWLEDGE AND ATTITUDE ABOUT FLOUR ALBUS AMONG WOMEN OF REPRODUCTIVE AGE IN YOGYAKARTA
}

\author{
Suhita Tri Oklaini'), Sumarni.DW²), Esti Nugraheny3) \\ 1)Masters Program of Applied Midwifery STIKES Guna Bangsa, Yogyakarta \\ 2)Faculty of Medicine, Public Health, and Nursing, Universitas Gajah Mada, Yogyakarta \\ 3)Academy of Midwifery Ummi Khasanah, Bantul, Yogyakarta
}

\begin{abstract}
Background: Fluor albus is a problem which often occurs in women of all ages, especially in the ages of 45 years and over. The fluor albus (vaginal discharge leukorea), i.e. the discharge from the vagina beside blood, may be secretions, transudation or exudates from organs or lesions of the genital tract. Media aids such as leaflet and module are one of the most important components in the teaching and learning process. This study was aimed to determine the comparison of module effectiveness to improve knowledge and attitude about flour albus among women of reproductive age in Yogyakarta.

Subjects and Method: This was a quasi-experiment pretest-posttest design with control group design conducted at HUNTAP Pagerjurang Kepuharjo, Cangkringan, Yogyakarta. A sample of 178 women of reproductive age were selected for this study and divided into two groups: 34 in experiment (module) group and 34 in control (leaflet) group. The dependent variables were knowledge and attitude about fluor albus. The independent variable was types of media aid. The data were collected by questionnaire and analyzed by t-test and Mancova.

Results: After the intervention, increase of mean scores in both knowledge and attitude in the module group were higher than the leaflet group, and they were statistically significant. Conclusion: Module is more effective than leaflet as a health education media aid to increase knowledge and attitude about fluor albus.
\end{abstract}

Keywords: module, knowledge, attitude, flour albus, reproductive.

Correspondence:

Suhita Tri Oklaini. Masters Program of Applied Midwifery STIKES Guna Bangsa, Yogyakarta. Email: Trioklainisuhita@gmail.com. Mobile: 085273577497.

The $5^{\text {th }}$ International Conference on Public Health Best Western Premier Hotel, Solo, Indonesia, February 13-14, 2019 | 174

https://doi.org/10.26911/theicph.2019.02.19 